\title{
Analisis Pengaruh Komposisi Kepemilikan Terhadap Manajemen Laba Pada Perusahaan Yang Terdaftar Di Bursa Efek Indonesia
}

\author{
Mardianto $^{\mathrm{a}, *}$, Khellystina $^{\mathrm{b}}$ \\ aProgram Studi Akuntansi, Universitas Internasional Batam, mardianto.zhou@uib.ac.id, Batam \\ bProgram Studi Akuntansi, Universitas Internasional Batam, 1842184.khellystina@uib.edu, Batam
}

\begin{abstract}
This study aims to analyze the effect of ownership composition on earnings management in companies listed on the Indonesia Stock Exchange. This study method is quantitative research that emphasizes testing of variables through data in the form of numbers and analyzing data with statistical procedures. The population used in this study is the listed company from Indonesia Stock Exchange between 2016 - 2020 and for data testing tools using the SPSS 25 and Eviews 10. Ownership composition is represented by family ownership, institutional ownership, blockholder ownership, debt, firm size, return on equity and sales growth. The results of this study showed that debt is significantly positive on earnings management, sales growth is significant negative on earnings management. Meanwhile, family ownership, institutional ownership, blockholder ownership, firm size and return on equity show no significant results. All independent variables can explain the dependent variable by $31.45 \%$ based on the coefficient of determination test.
\end{abstract}

Keywords: Earnings management, Good corporate governance, ownership composition, Indonesia stock exchange

*Corresponding author. E-mail: mardianto.zhou@ uib.ac.id 


\section{Pendahuluan}

Laporan keuangan biasanya menjadi patokan bagi perusahaan untuk mengambil keputusan bisnis selanjutnya. Dalam suatu perusahaan, pihak manajer dan juga para pemegang saham tentunya memiliki visi dan misi yang sama yaitu hasil kinerja perusahaan yang baik. Maka dari itu pelaku bisnis harus dapat menciptakan kondisi lingkungan bisnis yang kreatif dan inovatif sehingga dapat menghasilkan laba yang menjadi ukuran dari keberhasilan perusahan. Semakin tinggi laba perusahaan yang didapatkan maka akan mencerminkan semakin banyak kesejahteraan yang dimiliki oleh pelaku perusahaan atau dapat dikatakan juga semakin banyak laba perusahaan maka kepercayaan publik terhadap perusahaan juga berbanding lurus. Dalam hal ini, perusahaan berusaha untuk memilih manajemen yang dapat membantu perusahaan dalam menghasilkan laba. Manajer, selaku pihak yang memiliki tanggungjawab dalam perusahaan juga harus bertanggungjawab atas nilai perusahaan. Akan tetapi, manajer juga memiliki keinginan atau tanggungjawab untuk mensejahterakan dirinya sendiri. Oleh karena itu, hal tersebut akan mengakibatkan terjadinya praktik manajemen laba dalam perusahaan.

Manajemen laba atau dengan bahasa lainnya yaitu manipulasi laporan keuangan merupakan tindakan yang dilakukan oleh pihak yang berwenang atau manajer perusahaan yang timbul karena adanya masalah keagenan antara manajer dan pemegang saham perusahaan Dechow (2010) sehingga manajer bertujuan untuk melakukan tindakan terhadap informasi pada laporan keuangan dengan tujuan low profit distribution, mengurangi basis pajak, dan meningkatkan kemungkinan terjadinya perolehan pinjaman serta meningkatkan kepercayaan para pemegang saham dengan cara merekayasa laporan keuangan. Ketika manajer melakukan pertimbangan terhadap laporan keuangan dan penyusunan transaksi untuk mengelabui para investor tentang kinerja perusahaan maka akan menyebabkan terjadinya manajemen laba (Ahmad, 2016)

Manajemen laba yang dilakukan oleh manajer dapat diminimalisirkan dengan mengimplementasikan tata kelola perusahaan yang merupakan sistem pengatur hubungan antara perusahaan dengan pemegang saham. Tata kelola perusahan memiliki beberapa bagian, salah satunya adalah komposisi kepemilikan. Kablan (2020) memjelaskan tentang komposisi kepemilikan adalah kategori pemegang saham dengan jumlah saham yang dimiliki, karena hal tersebut dapat menpengaruhi kinerja perusahaan kemudian komposisi kepemilikan juga berperan sangat penting dalam menjelaskan tindakan yang diambil ketika sebuah perusahaan mengalami kesulitan keuangan (Fan, 2013).

Di Indonesia, salah satu kasus manajemen laba yang saat ini menjadi pembicaraan hangat yaitu PT Garuda Indonesia (Persero) yang berhasil menyusun laporan laba rugi dengan menghasilkan laba bersih tahun 2018 sebesar Rp 11,56 milliar atau setara dengan US\$809 ribu sedangkan pada tahun 2017, Garuda Indonesia memiliki kerugian sebesar Rp 3,09 trilliun atau setara dengan US $\$ 216,58$ juta (Wirianata, 2020). Laba pada tahun 2018 ditopang oleh kerja sama antar garuda dan Mahata Aero yang bernilai sekitar US $\$ 239,94$ juta yang sesungguhnya dana tersebut masih bersifat piutang namun sudah diakui sebagai pendapatan. Terbongkarnya kasus tersebut dikarenakan adanya komisaris dari PT Garuda Indonesia yang merasa janggal dan tidak sesuai dengan pernyataan standar akuntasi keuangan (PSAK) yang kemudian diteruskan sampai kementerian keuangan, Bursa Efek Indonesia (BEI), Otoritas Jasa Keuangan (OJK) dan Badan Pemeriksa Keuangan (BPK) juga ikut serta dalam pelaksanaan audit laporan keuangan perusahaan pada kode saham GIAA tersebut.

San Martin Reyna (2018) mengemukakan bahwa komposisi kepemilikan pada perusahaan yang terdaftar di Bursa Efek Meksiko dapat mempengaruhi fungsi pengawasan dan kontrol yang berbeda terhadap strategi perusahaan yang akan berdampak pada manajemen laba. Penelitiannya mengungkapkan kepemilikan keluarga dan kepemilikan institusional dapat mengurangi terjadinya manajemen laba. Penelitian ini dilakukan untuk mengetahui pengaruh dari penerapan tata kelola perusahaan terhadap manajemen laba yang dijadikan dalam bentuk penelitian yang berjudul "Analisis Pengaruh Komposisi Kepemilikan terhadap Manajemen Laba pada Perusahaan yang Terdaftar di Bursa Efek Indonesia" dikarenakan manajemen laba merupakan hal yang umum dan sering menjadi perdebatan dalam dunia akuntansi.

\section{Kerangka Teoritis dan Perumusan Hipotesis}

Manajemen laba atau bahasa inggrisnya disebut dengan earnings management merupakan masalah yang sangat umum dan utama yang terjadi pada saat ini Alzoubi (2016) dan menjadi sebuah alternatif yang dilakukan oleh para manajer dalam menentukan 
kebijakan akuntansi guna mencapai tujuan-tujuan tertentu seperti mengatur pelaporan laba terhadap pemangku kepentingan (Ifada \& Wulandari, 2015). Selain itu, didalam praktik manajemen laba juga terjadi campur tangan yang mengarahkan pada keuntungannya sendiri dengan cara memanipulasi laporan keuangan seperti laporan laba rugi, dan neraca keuangan untuk menyesatkan para pemangku kepentingan (Wu, 2014).

Manajemen laba didefinisikan dengan menggunakan dua buah perspektif yaitu persepektif oportunistik dan persepektif informasional. Manajemen laba dengan persepektif oppurtunistik digunakan untuk menyesatkan investor terhadap kondisi suatu perusahaan (Mahjoub \& Miloudi, 2015). Perspektif opportunistik sangat mendukung para manajer dalam melakukan manajeman laba karena para manajer dapat menampilkan laba yang baik meskipun kondisi perusahaan sedang sulit sedangkan perspektif informasional digunakan untuk memberikan informasi pribadi terkait dengan kinerja masa depan perusahaan dan keputusan yang di ambil akan bersifat legal dan memberikan nilai yang tepat kepada pemangku kepentingan.

Manajer yang melakukan praktik manajemen laba bertujuan untuk menyalahgunakan laporan perusahaan yang memuat informasi mengenai kinerja keuangan perusahaan untuk memungkinkan para pemangku kepentingan membuat keputusan ekonomi dan laporan keuangan juga merupakan tolak ukur keberhasilan atau kegagalan sebuah perusahaan (Susanto, 2016). Manajamen laba memiliki tiga buah metode yang di perbolehkan oleh GAAP. Yang pertama adalah mengukur perbedaan menggunakan metode akuntansi untuk penilaian inventaris, yang kedua yaitu adanya unsur ketidakpastian antara jumlah dan waktu transaksi sedangkan yang ketiga yaitu ruang manipulasi oleh manajemen otoritas yang diizinkan dalam peraturan GAAP misalnya pendapatan yang diduga dan biaya.

Alexandri \& Anjani (2014) menyatakan bahwa manajemen laba terdapat 4 pola dasar yang digunakan oleh manajer yaitu pola taking a bath yang pada pola ini manajer cenderung melakukan penghilangan beberapa aset dan membebankan perkiraan biaya dimasa depan, pola profit maximization biasanya digunakan untuk mendapatkan bonus yang lebih besar dengan cara menaikkan laba bersih perusahaan, profit minimization hampir sama dengan pola taking a bath dimana pola tersebut manajer mencari cara untuk memperlancar penghapusan aktiva tetap dan aktiva tidak berwujud, dan yang terakhir yaitu pola income smoothing dimana pada pola ini memiliki tujuan untuk menormalisasi keuntungan atau untuk mencapai tingkat tertentu.

\section{Pengaruh Kepemilikan Keluarga terhadap Manajemen Laba}

Feng \& Huang (2020) mengemukakan tentang struktur pemegang saham perusahaan yang dikendalikan oleh keluarga, masalah keagenan fundamental bukanlah permasalahan antara manajer dan investor melainkan permasalahan antara investor minoritas dan pemilik pengendali yang menggunakan kepemilikan konsentrasi untuk mengambil alih pendapatan pemegang saham minoritas. Dengan demikian peningkatan kepemilikan keluarga dapat memaksa pemilik saham pengendali untuk mengelola pendapatan secara oportunistik sehingga konsentrasi kepemilikan dapat membatasi informasi akuntansi kepada investor luar. Penelitian ini menghasilkan pengaruh kepemilikan keluarga berdampak signifikan positif terhadap manajemen laba dimana hasil penelitian tersebut sejalan dengan penelitian yang dilakukan oleh Kumala \& Siregar (2020) yang menyatakan bahwa kepemilikan keluarga membawakan hasil yang positif terhadap manajemen laba dikarenakan para pemegang saham keluarga dapat mengendalikan para manajemen untuk melakukan tindakan diskresioner untuk meningkatkan laba pada laporan keuangan demi menguntungkan para pemegang saham. Hal tersebut di dukung oleh penelitian Paiva (2016), Wan Mohammad \& Wasiuzzaman (2019), dan Eddy O \& Oluku (2017). Namun adanya perbedaan pendapat dari Achleitner (2014) yang mengatakan bahwa kaitan antara kepemilikan keluarga dan manajemen laba bersignifikan negatif.

$\mathrm{H}_{1}=$ Kepemilikan keluarga berpengaruh signifikan positif terhadap praktik manajeman laba

\section{Pengaruh kepemilikan institusional terhadap Manajemen Laba}

Menurut gagasan dari Perdana (2019) yang menyatakan bahwa kepemilikan institutional merupakan bagian dari perusahaan yang dimiliki oleh institusi seperti bank, asuransi perusahaan dan yang lainnya, hasil dari penelitian tersebut menyatakan bahwa kepemilikan institutional memiliki pengaruh positif terhadap manajemen laba yang berarti semakin besarnya kepemilikan institutional dalam sebuah perusahaan maka semakin besar juga potensi dalam praktik manajemen laba dan sesuai dengan riset yang 
dilakukan oleh Pramithasari \& Yasa (2017) dan Lemma (2018) menyatakan bahwa kepemilikan institusional memiliki signifikan positif terhadap praktek manajemen laba.

Sesuai dengan paparan paragraf diatas, penjelasan studi tentang kesignifikan kepemilikan institusional terhadap manajemen laba tidak hanya positif namun ada perbedaan pendapat dari Pirzada (2019) yang menyatakan bahwa kepemilikan institusional bersignifikan negatif dikarenakan semakin tinggi kepemilikan institusional maka pengawasan manajemen dalam melakukan manajemen laba akan semakin ketat dan dapat mempengaruhi keputusan manajer sehingga ini menunjukkan bahwa investor institusional juga memiliki peran regulasi didalam perusahan. Pernyataan tersebut didukung oleh Ajay \& Madhumathi (2015), Lakhal (2015) dan Farooque \& Suyono (2018).

$\mathrm{H}_{2}=$ Kepemilikan institusional berpengaruh signifikan negatif terhadap praktik manajeman laba

\section{Pengaruh kepemilikan blockholder terhadap Manajemen Laba}

Penelitian yang dilakukan oleh Lassoued (2017) membahas mengenai dampak dari komposisi kepemilikan pada manajemen laba perbankan membuktikan bahwa kepemilikan blockholder akan berdampak pada kerugian diskresioner yang besar dalam ketentuan pinjaman. Hal ini dikarenakan kepemilikan blockholder dapat melakukan intervensi dalam mendukung praktik manajemen laba dan para blockholder juga akan menerima keuntungan dari harga saham yang tinggi (Jiang, 2020).

Hasil dari penelitian-penelitian yang telah dilakukan tidak selalu memberikan hasil yang konsisten, seperti menghasilkan hasil yang positif, negatif serta insignifikan. Berdasarkan gagasan dari Jiang (2020) mendapatkan hasil bahwa blockholder bersignifikan positif terhadap manajemen laba, kemudian menurut Ilmas (2018) kepemilikan blockholder bersignifikan negatif terhadap manajemen laba dikarenakan pemegang saham blockholder yang tinggi dapat mengontrol kinerja manajer sehingga para manajer tidak dapat melakukan manipulasi terhadap keuntungan pada laporan akuntansi dan penelitian tersebut didukung oleh penelitian yang dilakukan oleh Farouk \& Hassan (2014), Hessayri \& Saihi (2015) serta juga ada penelitian yang menyatakan bahwa kepemilikan blockholder tidak pengaruh signifikan terhadap manajemen laba yaitu peneltian dari Habbash (2013) dan sejalan dengan yang disampaikan oleh (Zulvina, 2015)

$\mathrm{H}_{3}=$ Kepemilikan blockholder berpengaruh signifikan negatif terhadap praktik manajeman laba

Pengaruh kebijakan hutang terhadap Manajemen Laba

Kebijakan hutang menunjukkan total jumlah aktiva suatu entitas yang dibiayai oleh hutang. Tingkat hutang yang tinggi akan menunjukkan resiko yang semakin tinggi bagi investor dan semakin tingginya resiko perusahaan maka akan semakin tinggi pula kemungkinan manajemen terlibat dalam praktek manajemen laba (Firnanti, 2019). Perusahaan yang memiliki hutang yang banyak cenderung akan tunduk kepada pengawasan yang ketat dan oleh karena itu perusahaan akan melaporkan informasi keuangan yang lebih berkualitas (Borralho, 2020).

Penelitian yang dilakukan oleh Moslemany \& Nathan (2019) menyatakan bahwa pengaruh hutang terhadap manajemen laba menunjukkan hasil signifikan positif, hal tersebut dapat dikaitkan dengan gagasan bahwa perusahaan dengan hutang tinggi cenderung melanggar perjanjian hutang dengan membuat pilihan untuk meningkatkan pendapatan akuntansi dalam melonggarkan batasan hutang mereka serta mencapai kondisi kontrak yang lebih baik, pernyataan diatas didukung oleh Lazzem \& Jilani (2017), Hoang \& Phung (2019), Borralho (2020) dan Saona, (2020). Adapun penelitian yang bertolak belakang yaitu penelitian dari Soliman \& Ragab (2013) yang mendapatkan hasil signifikan negatif.

$\mathrm{H}_{4}=$ Kebijakan hutang berpengaruh signifikan positif terhadap praktik manajeman laba

\section{Pengaruh ukuran perusahaan terhadap Manajemen Laba}

Ukuran perusahaan merupakan cerminan dari seberapa besar kekayaan yang dimiliki oleh perusahaan. Semakin besar ukuran perusahaan, maka semakin tinggi nilai atau kekayaan perusahaan yang dapat digunakan dalam mendukung aktivitas operasional usaha. Adanya pengaruh yang negatif diantara variabel ukuran perusahaan dan variabel manajemen laba sesuai dengan paparan dari Swastika (2013), Purnama \& Nurdiniah (2019) dimana pendapat tersebut didukung oleh Hassan \& Ahmed (2012) yang menyatakan bahwa semakin besar ukuran 
perusahaan, maka semakin kecil pula pengelolaan manajemen laba yang dilakukan di perusahaannya.

Pendapat yang telah dipaparkan diatas bertolak belakang dengan pendapat dari Alzoubi (2016) yang menyatakan bahwa variabel ukuran perusahaan mempergaruhi ataupun bersignifikan positif terhadap manajemen laba yang berkesimpulan bahwa perusahaan besar melalui total aset yang lebih tinggi dapat dikaitkan dengan manajemen laba untuk mencapai target laba tertentu. Pendapat diatas didukung oleh studi yang dilakukan oleh Ali (2015), Chen (2015), dan Patel (2020) yang menyatakan bahwa adanya hubungan positif antara ukuran perusahaan dengan manajemen laba karena perusahaan besar cenderung memililki tekanan yang lebih besar dari investor dan analis keuangan untuk menunjukkan laba atau kenaikan laba yang positif. $\mathrm{H}_{5}=$ Ukuran perusahaan berpengaruh signifikan positif terhadap praktik manajeman laba

\section{Pengaruh Return on Equity terhadap Manajemen Laba}

Return on Equity (ROE) diukur dari rasio laba bersih terhadap ekuitas pemegang saham. Return on Equity merupakan salah satu rasio profitabilitas yang dapat digunakan untuk mengukur tingkat kemampuan perusahaan dalam menghasilkan laba bersih kepada para pemegang saham sebagai salah satu pemangku kepentingan.

Studi yang dilakukan oleh Noe (2017) menyatakan bahwa Return on Equity bertanda positif karena manajer dapat meningkatkan laba perusahaan di laporan laba rugi melalui kekuasannya. Pendapat tersebut senada dengan penelitian dari Santo (2013) menyatakan bahwa Return on Equity bersignifikan positif terhadap manajemen laba dikarenakan para perusahaan ataupun manajer dapat memanipulasi laporan keuangannya untuk menunjukkan profitabilitas yang lebih tinggi, pendapat tersebut disepakati oleh Okoro \& Ihenyen (2020) tetapi pendapat ini bertolakbelakang dengan penelitian yang di lakukan oleh Qi (2013) dan Alhadab (2017) yang menghasilkan signifikan negatif.

$\mathrm{H}_{6}=$ Return on Equity berpengaruh signifikan positif terhadap praktik manajeman laba

\section{Pengaruh pertumbuhan penjualan terhadap Manajemen Laba}

Pertumbuhan penjualan dilihat dari peningkatan penjualan dari tahun ke tahun (Cassell, 2015).
Penelitian sebelumnya, Hu (2015) mendapatkan hasil signifikan negatif tentang pengaruh pertumbuhan penjualan terhadap manajemen laba namun studi tersebut bertolakbelakang dengan penelitian Hazarika (2012) dimana pada penelitian tersebut menunjukkan hasil variabel pertumbuhan penjualan tidak memiliki pengaruh signifikan terhadap manajemen laba.

Pengaruh pertumbuhan penjualan juga menunjukkan hasil signifikan positif yang ditunjukkan melalui penelitian yang dilakukan oleh Chi (2015) yang pendapat tersebut didukung oleh Maheshwari \& Agrawal (2015), Razzaque (2016), dan Ranjbar \& Amanollahi (2018) serta Edison (2020) dengan hasil penelitian yang menyatakan bahwa perusahaan dengan pertumbuhan tinggi mungkin akan kekurangan kas dan oleh karena itu, akrual di perusahaan tersebut cenderung akan lebih tinggi.

$\mathrm{H}_{7}=$ Pertumbuhan penjualan berpengaruh signifikan positif terhadap praktik manajeman laba

\section{Metode Penelitian}

\section{Jenis Penelitian}

Tujuan penelitian adalah untuk melakukan pengembangan pada teori yang sudah dijalankan sebelumnya. Penelitian ini bersifat kuantitatif karena sampel penelitian disajikan dalam bentuk angka atau bilangan. Penelitian ini menggunakan jenis data time series, hal ini dikarenakan sampel penelitian diambil dengan berdasarkan waktu sampel yaitu dimulai dari tahun 2016 hingga 2020 atau dapat dikatakan lebih dari satu periode.

Penelitian ini berfokus pada pengujian hipotesis melalui pengukuran variabel kuantitatif. Penelitian ini menggunakan model yang di kembangkan oleh penelitian terdahulu yang menggunakan metode kuantitatif untuk analisis kepemilikan keluarga, kepemilikan institusional, kepemilikan blockholder, hutang, ukuran perusahaan, profitabilitas dan pertumbuhan penjualan terhadap manajamen laba. Penelitian kuantitatif merupakan pendekatan untuk menguji teori objektif dengan menguji hubungan antar variabel sehingga pada akhirnya dapat dianalisa dengan menggunakan prosedur statistik.

\section{Variabel Dependen: Manajemen Laba}

Manajemen laba menurut Dang (2017) merupakan suatu tindakan yang diambil oleh manajer untuk mempengaruhi tingkat keuntungan yang besar. Rumus 
variabel manajemen laba yang di kembangkan oleh Jones (1991) sebagai berikut:

$$
\frac{\text { TAIit }}{\text { TAit-1 }}=\alpha\left(\frac{1}{\text { TAit-1 }}\right)+\alpha 2\left[\frac{(\Delta \text { Revit-ARit })}{\text { TAit- } 1}\right]+\alpha 3\left[\left(\frac{\Delta \text { PPE }}{\text { TAit-1 }}\right)\right]+\in \text { it }
$$

\section{Variabel Independen: Kepemilikan Keluarga}

Penelitian Setianto \& Sari (2017) mengungkapkan bahwa kepemilkan keluarga diukur berdasarkan saham perusahaan yang dimiliki oleh keluarga. Apabila semakin besar saham yang dimiliki oleh keluarga maka semakin besar juga kontrol yang dimiliki keluarga terhadap perusahaan. Kemudian Andres (2008) menyatakan bahwa insentif pada kepemilikan keluarga akan sangat kuat karena telah menginvestasikan sebagian besar kekayaan pribadi mereka. Rumus variabel kepemilkan keluarga yang dikembangkan oleh Darmadi (2016) sebagai berikut:

$$
\text { Kepemilikan keluarga }=\frac{\text { Jumlah saham kepemilkan keluarga }}{\text { Jumlah saham yang beredar }}
$$

\section{Variabel Independen: Kepemilikan Institusional}

Kepemilikan institusional merupakan kepemilikan jumlah saham perusahaan yang dimiliki oleh suatu institusi ataupun lembaga keuangan yang mengelola dana atas nama orang lain seperti asuransi, bank ataupun perusahaan investasi lainnya. Variabel kepemilikan institusional dapat diukur dengan persentase jumlah saham yang dimiliki oleh pemegang institusi terhadap total saham perusahaan. Rumus untuk menghitung kepemilikan institusional menurut Agustia (2013) yaitu:

$$
\text { Kepemilikan institusional }=\frac{\text { jumlah saham kepemilikan institusional }}{\text { Jumlah saham yang beredar }}
$$

\section{Variabel Independen: Kepemilikan Blockholder}

Kepemilikan blockholder merupakan kepemilikan jumlah saham perusahaan yang kepemilikannya paling sedikit 5\% dari keseluruhan saham perusahaan. Apabila semakin kecil kepemilikan blockholder maka semakin besar juga penggunaan hutang dalam mengambil keputusan. Variabel kepemilikan blockholder dapat di hitung dengan rumus yang dikembangkan oleh Basu (2016) sebagai berikut:

$$
\text { Kepemilikan blockholder }=\frac{\text { Saham yang dimiliki oleh blockholder }}{\text { Jumlah saham yang beredar }}
$$

\section{Variabel Independen: Kebijakan Hutang}

Hutang merupakan kewajiban yang mengharuskan debitur untuk membayar utang atau nilai lain yang telah di sepakati bersama kreditur yang melalui pinjaman dana yang di gunakan untuk kegiatan operasional usaha. Rumus yang digunakan untuk menghitung variabel kebijakan hutang dari peneliti San Martin Reyna (2018) adalah sebagai berikut:

$$
\text { Kebijakan Hutang }=\frac{\text { Total hutang }}{\text { Total aset }}
$$

\section{Variabel Independen: Ukuran Perusahaan}

Peneliti Nurdiniah \& Herlina (2015) mengatakan bahwa ukuran perusahaan merupakan suatu nilai yang menunjukkan seberapa besar perusahaan tersebut. Ukuran perusahaan dapat diukur dari total asset yang di miliki oleh perusahaan. Apabila semakin besar jumlah total asset yang dimiliki maka semakin besar juga ukuran perusahaan. Proksi yang digunakan dalam mengukut ukuran perusahaan menurut Rahnamay Roodposhti \& Nabavi Chashmi (2010) yaitu:

$$
\text { Ukuran perusahaan }=\log (\text { Total aset })
$$

\section{Variabel Independen: Return on Equity}

Menurut Mery (2017), profitabilitas merupakan pengukuran kinerja manajemen secara keseluruhan yang dinilai dari tingkat keuntungan yang diperoleh dari hasil penjualan. Semakin baik profitabililitas makan semakin baik kemampuan perushaan dalam menghasilkan laba. Rumus untuk mengukur profitabilitas menurut Gunawan (2015) yaitu:

$$
\text { Return on Equity }(\mathrm{ROE})=\frac{\text { laba bersih setelah pajak }}{\text { Total equity }} \times 100 \%
$$

\section{Variabel Independen: Pertumbuhan Penjualan}

Cassell (2015) menyimpulkan bahwa pertumbuhan penjualan atau diukur sebagai persentase perubahan pendapatan selama dari tahun ke tahun. Rumus yang digunakan untuk mengukur variabel pertumbuhan perusahaan menurut Arif (2015) yaitu:

$$
\text { Pertumbuhan penjualan }=\frac{\text { Penjualan saat ini }- \text { Penjualan masa lalu }}{\text { Penjualan masa lalu }} \times 100 \%
$$




\section{Statistik Deskriptif}

Analisis statistik deskriptif merupakan kumpulan dari berbagai macam angka dengan tujuan untuk menjelaskan atau menyajikan data menjadi sebuah informasi yang mudah untuk dimengerti (Nasution, 2017).

\section{Regresi Panel}

Regresi data panel merupakan gabungan antara time series dan cross section. Ada beberapa model yang dapat digunakan dalam menentukan model regresi yaitu:

a. Commen Effect Model (CEM), model yang paling sederhana karena tidak membedakan waktu dan objek sehingga tidak mempengaruhi error regresi dan bersifat tetap.

b. Fixed Effect Model (FEM) mengestimasi data panel dimana perbedaan objek dan waktu dapat mempengaruhi regresi dan bersifat tetap.

c. Randomc Effect Model (REM) mengasumsi bahwa perbedaan objek dan waktu dapat mempengaruhi error regresi dan bersifat random.

\section{Pemilihan Model Terbaik}

Pemilihan model regresi dilakukan untuk memudahkan dalam menentukan metode regresi yang sesuai dengan situasi data. Biasanya tahap pertama yang dilakukan untuk menentukan model regresi yaitu dengan melakukan uji chow untuk menentukan model yang cocok antara model CEM atau FEM. Ketika uji chow membuktikan bahwa hasil yang cocok adalah model FEM, maka tahap selanjutnya adalah uji hausman dengan tujuan untuk menentukan model yang cocok antara FEM dan REM.

Uji Chow di lakukan untuk memperoleh model yang cocok antara CEM atau FEM. Hasil uji chow dalam dilihat melalui cross-section Chi-square. Apabila nilai profitabilitas menunjukkan $<0,05$ maka model yang cocok adalah model FEM. Sedangakn untuk nilai profitabilitas $>0,05$ maka model yang cocok adalah model CEM.

Uji Hausman dilakukan ketika pada uji chow menghasilkan model FEM, dan maka harus melanjutkan ke uji hausman. Hasil uji hausman dapat dilihat dengan nilai probabilitas. Apabila nilai probabilitas menunjukkan < 0,05 maka model yang harus digunakan adalah model FEM dan ketika nilai ptobabilitias menunjukkan $>0,05$ maka model yang cocok adalah model REM.
Uji Lagrance dilakukan ketika hasil pada uji hausman menunjukkan model REM maka langkah selanjutnya ada melakukan uji Lagrance untuk menghasilkan model yang tepat antara CEM dan REM. Ketika hasil uji menunjukkan nilai Lagrance > chi-squared maka model yang tepat adalah REM sedangkan apabila nilai Lagrance < chi-squared maka model yang sesuai adalah CEM.

\section{Uji Hipotesis}

Uji hipotesis bertujuan untuk mengetahui seberapa besar pengaruh variabel independen terhadap variabel dependen. Aplikasi yang digunakan untuk menguji hipotesis yaitu aplikasi Eviews 10. Berikut merupakan uji hipotesis yang dilakukan.

Uji F dilakukan untuk menguji pengaruh seluruh variabel independen terhadap variabel dependen secara simultan. Ada beberapa kriteria dalam uji F, yakni jika nilai signifikansi $<0,05$ maka artinya variabel independen berpengaruh secara simultan terhadap variabel dependen, Jika nilai signifikansi > 0,05 maka artinya variabel independen tidak berpengaruh simultan terhadap variabel dependen.

Uji T dipakai untuk mengetahui apakah adanya variabel independen yang mempengaruhi variabel dependen. Ada beberapa persyaratan yang dipakai dalam uji T, yakni jika nilai signifikansi $<0,05$ berarti variabel independen berpengaruh secara parsial terhadap variabel dependen dan Jika nilai signifikansi $>0,05$ berarti variabel independen tidak berpengaruh parsial terhapap variabel dependen.

Uji Goodness of Fit disebut sebagai uji koefisien determinasi $\left(\mathrm{R}^{2}\right)$ yang berfungsi untuk mengkonfirmasi penerapan model regresi yang diperoleh dari regresi panel. Uji $\mathrm{R}^{2}$ menggambarkan model yang sesuai atau persentase nilai sejauh variabel independen dapat menjelaskan variabel dependen.

\section{Analisis dan Pembahasan}

\section{Statistik Deskriptif}

Laporan keuangan tahunan merupakan data sekunder yang diperoleh dari BEI pada tahun 20162020. Hasil pendataan menunjukkan adanya 720 perusahaan yang tercatat di dalam BEI hingga tahun 2020. sebanyak 415 perusahaan yang tidak memenuhi kriteria penelitian maka harus di keluarkan dari sampel penelitian sehingga memperoleh 1500 data yang diobservasi. Kemudian, dilakukan uji outlier dan menghasilkan data sampel sebanyak 1473 data. 
Tabel 1

Hasil Uji Statistik Deskriptif

\begin{tabular}{|c|c|c|c|c|c|}
\hline \multirow{2}{*}{ Keterangan } & \multicolumn{5}{|c|}{ Statistik Deskriptif } \\
\hline & $\mathbf{N}$ & Minimum & Maximum & Mean & $\begin{array}{c}\text { Std. } \\
\text { Deviation }\end{array}$ \\
\hline $\begin{array}{l}\text { Manajemen } \\
\text { Laba } \\
\text { Kepemilikan }\end{array}$ & 1473 & 0,00001 & 0,51289 & 0,75415 & 0,74274 \\
\hline $\begin{array}{l}\text { Keluarga } \\
\text { Kepemilikan }\end{array}$ & 1473 & 0,00000 & 0,98307 & 0,36215 & 0,31754 \\
\hline $\begin{array}{l}\text { Institusional } \\
\text { Kepemilikan }\end{array}$ & 1473 & 0,00000 & 1,00000 & 0,62259 & 0,25424 \\
\hline $\begin{array}{l}\text { Blockholder } \\
\text { Kebijakan }\end{array}$ & 1473 & 0,00000 & 1,00000 & 0,71202 & 0,18085 \\
\hline $\begin{array}{l}\text { Hutang } \\
\text { Ukuran } \\
\text { Perusahaan } \\
\text { (Miliar) }\end{array}$ & 1473 & 0,00473 & 14,33974 & 0,55129 & 0,74453 \\
\hline $\begin{array}{l}\text { ROE } \\
\text { Pertumbuhan }\end{array}$ & 1473 & $-13,83582$ & 33,49453 & 0,20483 & 0,61325 \\
\hline $\begin{array}{l}\text { Penjualan } \\
\text { Valid N } \\
\text { (listwise) }\end{array}$ & $\begin{array}{l}1473 \\
1473\end{array}$ & $-1038,8135$ & 902,55801 & 0,69343 & 35,96559 \\
\hline
\end{tabular}

Nilai minimum manajemen laba berada pada angka 0,00001 dan nilai maksimum berada pada angka 0,51289 sedangkan nilai rata-rata menunjukkan nilai sebesar 0,75415 dan standar deviasi menunjukkan 0,74274 artinya variasi data tersebut dapat dikatakan cukup tinggi.

Dari hasil uji tabel 1, dapat disimpulkan bahwa adanya perusahaan yang tidak memiliki pemegang saham keluarga karena didominasi oleh kepemilikan pemerintah atau perusahaan luar negeri seperti PT Astra Agro Lestari Tbk, PT Akasha Wira International Tbk, PT Adindo Foresta Indonesia Tbk, PT Adhi Karya Persero Tbk dan lainnya sedangkan perusahaan dengan kepemilikan keluarga tertinggi dimiliki oleh PT Solusi Bangun Indonesia Tbk dengan kepemilikan sebesar 98,31\%. Kepemilikan keluarga memiliki nilai rata-rata sebesar $36,22 \%$ sehingga menduduki posisi terakhir apabila dibandingkan dengan rata-rata pemegang saham institusional dan blockholder.

Berdasarkan tabel 1, kepemilikan institusional memiliki nilai terendah yang berada pada $0,00 \%$ yang menandakan adanya pemegang saham perusahaan yang tidak dimiliki oleh institusi seperti PT Adhi Karya (Persero) Tbk, PT Arthavest Tbk, PT Binakarya Jaya Abadi Tbk, PT Betonjaya Manunggal Tbk dan lainnya. Sedangkan pemegang saham institusi tertinggi dimiliki oleh PT Fajar Surya Wisesa Tbk secara berturut-turut dari tahun 2019 hingga tahun 2020 dengan kepemilikan sebesar $100 \%$. Nilai ratarata dari kepemilikan institusional sebesar $62,26 \%$, jika dilihat dari tabel 1 maka dapat disimpulkan bahwa pemilik institusi menduduki posisi kedua pemegang saham terbanyak setelah kepemilikan blockholder.

Dari tabel 1, kepemilikan blockholder menunjukkan nilai minimum sebesar $0,00 \%$ yang berarti adanya perusahaan yang memiliki jumlah kepemilikan kurang dari 5\% seperti PT Bakrie Sumatera Plantations Tbk dan PT Aneka Tambang Tbk yang berturut-turut dari tahun 2016 hingga tahun 2019 dan nilai maksimum sebesar $100 \%$ yang diraih oleh PT Rukun Raharja Tbk pada tahun 2020. Dari tabel diatas, dapat disimpulkan bahwa pemegang saham blockholder mendominasi pemegang saham keluarga dan institusional dengan nilai rata-rata sebesar $71,20 \%$.

Berdasarkan tabel statistik deskriptif diatas, dapat dilihat bahwa hasil pengujian menunjukan nilai hutang mencapai 14,33974 kali lebih besar daripada jumlah aset yang dimiliki sehingga perusahaan belum cukup mampu untuk melunasi hutangnya. Sedangkan rasio hutang pada nilai minimum di capai oleh PT Adindo Foresta Indonesia Tbk pada tahun 2020 sebesar 0,00473 yang membuktikan bahwa perusahaan tersebut mampu untuk membayar hutangnya. Nilai rata-rata dari kebijakan hutang adalah 0,55129 yang artinya setiap Rp 1 utang perusahaan dapat ditanggung dengan $\mathrm{Rp} 0,55$ aset perusahaan.

Dari tabel 1 yang menggunakan 1473 sampel perusahaan menampilkan ukuran perusahaan terkecil dimiliki oleh PT Wilton Makmur Indonesia Tbk dengan total asset sebesar $\mathrm{Rp}$ 6.486.972.072 sedangkan ukuran perusahaan terbesar di raih oleh PT Astra Internasional Tbk dengan total aset yang mencapai Rp 351.958.000.000.000, Rata-rata perusahaan memiliki total aset sebesar $\mathrm{Rp}$ 3.605.000.000.000

Hasil uji statistik ROE menunjukkan rasio terendah berada pada nilai $-13,83582$ yang dimiliki oleh PT Air Asia Indonesia Tbk pada tahun 2017 sedangkan rasio tertinggi dengan nilai 7,55573 diraih oleh PT Mitra Investindo Tbk pada tahun 2019. Rasio dari return on equity dapat menyentuh nilai negatif dikarenakan perusahaan mengalami kerugian pada tahun berjalan. Nilai rata-rata pada variabel ini berada pada 2,05\% yang artinya perusahaan dapat menghasilkan laba sebesar 2,05\% dari modal yang disetorkan.

Hasil uji menyajikan pertumbuhan penjualan terendah berada pada nilai $-1038,81350$ yang artinya penjualan perusahaan tersebut turun drastis dibandingkan dengan tahun sebelumnya. Penurunan penjualan ini terjadi pada PT Pool Advista Indonesia 
Tbk pada tahun 2019. Pertumbuhan penjualan tertinggi di capai oleh PT Bumi Resources Minerals Tbk pada tahun 2019 yang meningkat hingga 902,55801 kali dibandingkan dengan tahun sebelumnya. Rata-rata pertumbuhan penjualan mengalami kenaikan sebesar Rp 0,69 pada setiap Rp 1 penjualan.

Uji Chow

Tabel 2

Hasil Uji Chow

\begin{tabular}{lccc}
\hline \multicolumn{1}{c}{ Effect Test } & Statistic & Prob. & Kesimpulan \\
\hline $\begin{array}{l}\text { Cross-section F } \\
\text { Cross-section }\end{array}$ & $2,597970,0000$ & \\
Chi-Square & $752,03580,0000$ & Fixed Effect Model \\
\hline
\end{tabular}

Sumber: Data penelitian diolah (2021)

Tabel 2 menunjukkan nilai probabilitis berada pada angka 0,0000 artinya model yang digunakan dalam penelitian adalah model FEM. Langkah selanjutnya adalah melakukan uji hausman untuk menentukan model FEM atau model REM yang sesuai dalam penelitian ini.

\section{Uji Hausman}

Tabel 3

Hasil Uji Hausman

\begin{tabular}{|c|c|c|c|}
\hline $\begin{array}{c}\text { Test } \\
\text { Summary }\end{array}$ & $\begin{array}{c}\text { Chi-Sq } \\
\text { Statistic }\end{array}$ & Prob. & Kesimpulan \\
\hline $\begin{array}{l}\text { Cross- } \\
\text { section } \\
\text { random }\end{array}$ & 14,604338 & 0,041 & Fixed Effect Model \\
\hline
\end{tabular}

Dilihat dari tabel 3 diatas, dapat diketahui bahwa model regresi terbaik yang digunakan dalam penelitian ini adalah FEM dikarenakan nilai probabilitas menunjukkan angka lebih dari 0,05 .

Uji F

\begin{tabular}{lcc}
\multicolumn{3}{c}{ Tabel 4} \\
& Hasil Uji F \\
\hline $\begin{array}{l}\text { Variabel } \\
\text { Dependen }\end{array}$ & Signifikan & Kesimpulan \\
\hline $\begin{array}{l}\text { Manajemen } \\
\text { Laba }\end{array}$ & 0,00000 & Signifikan \\
\hline Sumber: Data penelitian diolah (2021)
\end{tabular}

Dari tabel 4 hasil pengujian membuktikan nilai probabilitas sebesar 0,000000. Hasil tersebut dapat disimpulkan bahwa kepemilikan keluarga, kepemilikan institusional, kepemilikan blockholder, kebijakan hutang, ukuran perusahaan, ROE dan pertumbuhan penjualan secara simultan berpengaruh signifikan terhadap manajemen laba.

Uji $t$

Tabel 5

Hasil Uji T

\begin{tabular}{|c|c|c|c|c|}
\hline Variabel & Koefisien & Prob. & Kesimpulan & Hipotesis \\
\hline Constant & 0,16976 & 0,3984 & & \\
\hline $\begin{array}{l}\text { Kepemilikan } \\
\text { Keluarga } \\
\text { Kepemilikan }\end{array}$ & $-0,02344$ & 0,1431 & Tidak Sig. & Tidak Terbukti \\
\hline $\begin{array}{l}\text { Institusional } \\
\text { Kepemilikan }\end{array}$ & 0,003321 & 0,1809 & Tidak Sig. & Tidak Terbukti \\
\hline $\begin{array}{l}\text { Blockholder } \\
\text { Kebijakan }\end{array}$ & $-0,01508$ & 0,6185 & Tidak Sig. & Tidak Terbukti \\
\hline $\begin{array}{l}\text { Hutang } \\
\text { Ukuran }\end{array}$ & 0,01675 & 0,0165 & Sig. Positif & Terbukti \\
\hline $\begin{array}{l}\text { Perusahaan } \\
\text { (Miliar) }\end{array}$ & $-0,00363$ & 0,5954 & Tidak Sig. & Tidak Terbukti \\
\hline $\begin{array}{l}\text { ROE } \\
\text { Pertumbuhan }\end{array}$ & 0,005 & 0,1115 & Tidak Sig. & Tidak Terbukti \\
\hline Penjualan & $-0,00013$ & 0,0119 & Sig. Negatif & Tidak Terbukti \\
\hline
\end{tabular}

Berikut merupakan persamaan regresi yang terbentuk dari model penelitian:

DAI $=0,16976-0,02344$ Famown + 0,03321 Inst $-0,01508$ Ebh + 0,01675 Debt - 0,00363 Size + 0,00500 ROE 0,00013 Growth $+\mathrm{e}$

Keterangan:

DAI = Manajemen laba

Famown = Kepemilikan keluarga

Inst = Kepemilikan institusional

Ebh = Kepemilikan blockholder

Debt = Kebijakan hutang

Size $\quad=$ Ukuran perusahaan

ROE = Return on Equity

Growth $\quad=$ Pertumbuhan penjualan

$\mathrm{e}=$ Error

1. Hasil Pengujian $\mathrm{H}_{1}$

Signifikasi variabel kepemilikan keluarga dapat dilihat dari nilai probabilitas. Nilai probabilitas 
sebesar 0,1431 membuktikan bahwa signifikasi tersebut berada diatas 0,05 artinya variabel tersebut tidak memiliki pengaruh signifikan terhadap variabel dependen. Hal ini dapat terjadi karena adanya pemegang saham keluarga yang memiliki kontrol penuh terhadap laporan keuangan sehingga terlibat dalam manajemen laba tetapi ada juga perusahaan keluarga yang tidak terlibat dalam aktivitas yang memiliki dampak negatif pada nilai perusahaan. Hasil penelitian ini didukung oleh Cherif (2020) sehingga hipotesis 1 ditolak.

2. Hasil Pengujian $\mathrm{H}_{2}$

Kepemilikan institusional juga mendapatkan hasil yang tidak signifikan terhadap manajemen laba. Hasil tersebut dapat dilihat pada tabel 5 yang menunjukkan angka profitabilitas sebesar 0,1809 dengan koefisien pada 0,0332. Signifikasi pada bagian ini berada di atas 0,05 sehingga hipotesis 2 ditolak. Kepemilikan insitusional juga tidak dapat menjadi penentu dalam praktik manajemen laba karena pemegang saham insititusi hanya berfokus pada laba jangka pendek. Hasil ini didukung oleh peneliti Bao \& Lewellyn (2017).

3. Hasil Pengujian $\mathrm{H}_{3}$

Berdasarkan hasil uji diatas, kepemilikan blockholder menunjukkan hasil yang tidak berpengaruh signifikan terhadap manajemen laba sehingga hipotesis 3 ditolak. Kesimpulan ini dapat dilihat melalui angka probabilitas yang menunjukkan angka 0,6185 dengan koefisien pada -0,01508 yang dapat disimpulkan bahwa tidak ada pengaruh kepemilikan blockholder terhadap manajemen laba. Besar kecilnya pemegang saham blockholder tidak akan berpengaruh terhadap fungsi pengontrolan kinerja suatu perusahaan sehingga tidak mempengaruhi kebijakan manajemen perusahaan. Hasil tersebut sejalan dengan penelitian yang dilakukan oleh Habbash (2013) dan Zulvina (2015).

4. Hasil Pengujian $\mathrm{H}_{4}$

Hipotesis ini terbukti sejalan dengan hasil pengujian regresi pada penelitian ini. Nilai signifikasi hasil uji bernilai 0,0165 dengan koefisien sebesar 0,01675. Hasil signifikan positif menandakan bertambahnya hutang akan memicu terjadinya manajemen laba. Hal ini didasari dengan meningkatnya liabilitas jangka panjang maupun jangka pendek akan memicu resiko perusahaan. Perusahaan dengan hutang lebih tinggi akan lebih mendorong manajer untuk melakukan manipulasi laporan keuangan. Hasil signifikan positif ini sejalan dengan penelitian yang dilakukan oleh Moslemany \& Nathan (2019) dan Borralho (2020).

5. Hasil Pengujian $\mathrm{H}_{5}$

Hasil uji memberikan indikasi bahwa ukuran perusahaan tidak mempengaruhi manajer untuk melakukan praktik manajemen laba dikarenakan signifikansi probabilitas berada di atas 0,05 sehingga hipotesis 5 ditolak. Besar kecilnya perusahaan tidak akan mempengaruhi terjadinya manajemen laba karena perbedaan pendapat seperti perusahaan yang besar cenderung memiliki aset yang banyak sehingga khawatir untuk melakukan praktik manajemen laba karena akan memicu perhatian publik sedangkan pendapat lainnya yaitu dengan adanya penambahan aset akan memicu terjadinya praktik manajemen laba. Hasil penelitian ini sejalan dengan penelitian yang dilakukan oleh Putri \& Machdar (2018).

6. Hasil Pengujian $\mathrm{H}_{6}$

Hasil pada pengujian ini menunjukkan nilai probabilitas yang tercatat pada angka 0,1115 disertai dengan koefisien bernilai 0,00500. Hasil tersebut bertolak belakang dengan peneliti Qi (2013) tetapi didukung oleh peneliti Oz \& Yelkenci (2018) sehingga menunjukkan bahwa hipotesis 6 ditolak.

7. Hasil Pengujian $\mathrm{H}_{7}$

Profitabilitas pertumbuhan penjualan dapat dilihat pada tabel 5 yang menunjukkan nilai 0,0119 dengan koefisien pada -0,00013. Hasil ini menunjukkan bahwa pertumbuhan penjualan bersignifikan negatif sehingga hipotesis 7 ditolak. Peningkatan penjualan dari tahun ke tahun akan mengurangi atau meminimalkan manajer dalam melakukan praktik manajemen laba karena pembiayaan beban dapat dibayar dengan laba yang didapatkan dari penjualan sehingga kecil kemungkinan manajer untuk melakukan tindakan manipulasi laba. Hasil tersebut di dukung oleh $\mathrm{Hu}$ (2015).

Uji Goodness of Fit

Tabel 6

Hasil Goodnes of Fit

\begin{tabular}{lc}
\hline Variabel Dependen & \multicolumn{1}{c}{ Adjusted R-Squared } \\
\hline Manajemen Laba & 0,31453 \\
\hline Sumber: Data penelitian diolah (2021)
\end{tabular}

Hasil uji goodness of fit menunjukkan bahwa adjusted $R$-squared dari pengujian mendapatkan nilai sebesar 0,31453 yang mendefinsikan bahwa variabel 
independen yang terdiri dari kepemilikan keluarga, kepemilikan institusional, kepemilikan blockholder, kebijakan hutang, ukuran perusahaan, ROE dan pertumbuhan penjualan dapat menjelaskan pengaruhnya pada manajeman laba sebesar $31,45 \%$ sedangkan $68,55 \%$ sisanya diungkapkan oleh variabel lainnya.

\section{Kesimpulan, Keterbatasan dan Saran}

\section{Kesimpulan}

Untuk mengetahui pengaruh tata kelola perusahaan terhadap manajemen laba dimana tata kelola perusahaan diwakili oleh kepemilikan keluarga, kepemilikan institusional, kepemilikan blockholder, kebijakan hutang, ukuran perusahaan, ROE dan pertumbuhan penjualan dan penelitian ini menggunakan data sekunder yang di peroleh dari BEI pada tahun 2016-2020 dan tidak mengambil perusahaan perbankan untuk dijadikan sampel penelitian.

Berdasarkan hasil uji penelitian menunjukkan bahwa kepemilikan keluarga, kepemilikan institusional, kepemilikan blockholder, ROE dan pertumbuhan penjualan tidak berpengaruh signifikan terhadap manajemen laba sedangkan kebijakan hutang berpengaruh signifikan positif dan ukuran perusahaan memiliki pengaruh signifikan negatif terhadap manajemen laba. Kemudian seluruh variabel telah mampu menjelaskan variabel dependen mencapai $31,45 \%$ berdasarkan uji koefisien determinasi.

\section{Keterbatasan}

Dalam suatu penelitian pasti tidak akan terlepas dari keterbatasan, seperti:

1. Variabel independen dalam penelitian ini belum cukup banyak yakni hanya beberapa variabel yaitu kepemilikan keluarga, kepemilikan institusional, kepemilikan blockholder, kebijakan hutang, ukuran perusahaan, ROE, dan pertumbuhan penjualan sehingga menyebabkan lingkup penelitian masih kurang luas.

2. Sampel penelitian terbatas pada rentang waktu 5 tahun dan hanya menggunakan perusahaan yang teregistrasi di BEI yang menyajikan laporan tahunan serta laporan keuangan yang memenuhi kriteria penelitian ini. Dan sekitar lebih dari 400 perusahaan yang tersedia di BEI belum memenuhi keseluruhan kriteria penelitian.

Saran

Untuk menghindari keterbatasan tersebut, peneliti menyarankan beberapa rekomendasi yaitu:

1. Untuk memperluas lingkup penelitian, peneliti menyarankan untuk dapat menambah beberapa variabel indenpenden sehingga hasil penelitian dapat memberikan pengaruh signifikan terhadap manajemen laba

2. Rentang waktu untuk sampel penelitian dapat di perpanjang menjadi 10 tahun untuk mendapatkan hasil yang lebih tepat dan dapat mencoba meneliti perusahaan terbuka di negara lain untuk menjadikan perbandingan antara negara Indonesia dan negara lain.

\section{Referensi}

Achleitner, A., Günther, N., Kaserer, C., \& Siciliano, G. (2014). Real Earnings Management and Accrual-based Earnings Management in Family Firms. European Accounting Review, 23(3), 431-461.

Agustia, D. (2013). Pengaruh Faktor Good Corporate Governance, Free Cash Flow, dan Leverage Terhadap Manajemen Laba. Jurnal Akuntansi Dan Keuangan, 15(1), 27-42.

Ahmad, L., Suhara, E., \& Ilyas, Y. (2016). The Effect of Audit Quality on Earning Management within Manufacturing Companies Listed on Indonesian Stock Exchange. Research Journal of Finance and Accounting Www.Iiste.Org ISSN, 7(8), 132-138.

Ajay, R., \& Madhumathi, R. (2015). Institutional Ownership and Earnings Management in India. Indian Journal of Corporate Governance, 8(2), 119-136.

Alexandri, M. B., \& Anjani, W. K. (2014). Income Smoothing: Impact Factors, Evidence in Indonesia. International Journal of Small Business and Entrepreneurship Research, 3(1), 21-27.

Alhadab, M. M., \& Own, B. E. S. A.-. (2017). Earnings Management and Banks Performance: Evidence from Europe. International Journal of Academic Research in Accounting, Finance and Management Sciences, 7(4).

Ali, U., Noor, M., Khurshid, M. K., \& Mahmood, A. (2015). Impact of Firm Size on Earnings Management: A Study of Textile Sector of Pakistan. SSRN Electronic Journal, 7(28), 47-56.

Alzoubi, E. S. S. (2016). Ownership structure and earnings management: Evidence from Jordan. International Journal of Accounting and Information Management, 24(2), 135-161.

Andres, C. (2008). Large shareholders and firm performance-An empirical examination of founding-family ownership. Journal of Corporate Finance, 14(4), 431-445. 
Arif, S. (2015). Pengaruh Perputaran Modal Kerja, Leverage Dan Pertumbuhan Penjualan Terhadap Profitabilitas (Studi Pada Perusahaan Makanan Dan Minuman Yang Terdaftar Di Bursa Efek Indonesia Pada Tahun 2011-2013). Jurnal Administrasi Bisnis S1 Universitas Brawijaya, 27(1), 86329.

Bao, S. R., \& Lewellyn, K. B. (2017). Ownership structure and earnings management in emerging markets-An institutionalized agency perspective. International Business Review, 26(5), 828-838.

Basu, N., Paeglis, I., \& Rahnamaei, M. (2016). Multiple blockholders, power, and firm value. Journal of Banking and Finance, 66(January), 66-78.

Borralho, J. M., Vázquez, D. G., \& Hernández-Linares, R. (2020). Earnings management in private family versus non-family firms. The moderating effect of family business generation. Revista Espanola de Financiacion y Contabilidad, 49(2), 210-233.

Cassell, C. A., Myers, L. A., \& Seidel, T. A. (2015). Disclosure transparency about activity in valuation allowance and reserve accounts and accruals-based earnings management. Accounting, Organizations and Society, 46(1), 23-38.

Chen, X., Cheng, Q., \& Wang, X. (2015). Does increased board independence reduce earnings management? Evidence from recent regulatory reforms. Review of Accounting Studies, 20(2), 899-933.

Cherif, Z. F., Damak Ayadi, S., \& Ben Hamad, S. B. (2020). The effect of family ownership on accrual-based and real activities based earnings management: Evidence from the French context. Journal of Accounting and Management Information Systems, 19(2), 283310.

Chi, C. W., Hung, K., Cheng, H. W., \& Tien Lieu, P. (2015). Family firms and earnings management in Taiwan: Influence of corporate governance. International Review of Economics and Finance, 36, $88-98$.

Dang, N. H., Hoang, T. V. H., \& Tran, M. D. (2017). Factors affecting earnings management: The case of listed firms in Vietnam. International Journal of Economic Research, 14(20), 117-134.

Darmadi, S. (2016). Ownership concentration, family control, and auditor choice: Evidence from an emerging market. Asian Review of Accounting, 24(1), 19-42.

Dechow, P., Ge, W., \& Schrand, C. (2010). Understanding earnings quality: A review of the proxies, their determinants and their consequences. Journal of Accounting and Economics, 50(2-3), 344-401.

Dwi Lusi Tyasing Swastika, D. L. T. S. (2013). Corporate Governance, Firm Size, and Earning Management: Evidence in Indonesia Stock Exchange. IOSR Journal of Business and Management, 10(4), 77-82.

Eddy O, O., \& Oluku, M. D. (2017). Ownership Structure and Earnings Management Practices of Nigerian Companies. Journal of Internet Banking and Commerce, 22(S8), 1-8.

Edison, A., Purwo, A., Nugroho, A., Widyatama, U., Edison, A., \& On, S. G. (2020). The Effect Of Leverage And Sales Growth On Earning Management. Palarch's Jpurnal of Archaelogy of Egypt/Egyptology, 17(4), 3442-3454.

Fan, J. P. H., Huang, J., \& Zhu, N. (2013). Institutions, ownership structures, and distress resolution in China. Journal of Corporate Finance, 23, 71-87.
Farooque, O. Al, \& Suyono, E. (2018). Do Governance Mechanisms Deter Earnings Management and Promote Corporate Social Responsibility? Accounting Research Journal, 31(3), 479-495.

Farouk, M. A., \& Hassan, S. U. (2014). Influence of Possession Formation on Earnings Management of Quoted Chemical and Paints Firms in Nigeria. Journal of Management Policies and Practices, 2(2), 167-186.

Feng, Z. Y., \& Huang, H. W. (2020). Corporate governance and earnings management: A quantile regression approach. International Journal of Finance and Economics, 20(2).

Firnanti, F., Pirzada, K., \& Budiman, B. (2019). Company Characteristics, Corporate Governance, Audit Quality Impact on Earnings Management. GATR Accounting and Finance Review, 4(2), 43-49.

Gunawan, K., Darmawan, A. S., \& Purnamawati, I. G. A. (2015). Pengaruh Ukuran Perusahaan, Profitabilitas, dan Leverage Terhadap Manajemen Laba pada Perusahaan Manufaktur yang Terdaftar Di Bursa Efek Indonesia. E-Journal S1 AK Universitas Pendidikan Ganesha, 03(01).

Habbash, M. (2013). Earnings management, audit committee effectiveness and the role of blockholders ownership: Evidence from UK large firms. International Journal of Business Governance and Ethics, 8(2), 155-180.

Hassan, S. U., \& Ahmed, A. (2012). Corporate Governance , Earnings Management and Financial Performance: A Case of Nigerian Manufacturing Firms. American International Journal of Contemporary Research, 2(7), 214-226.

Hazarika, S., Karpoff, J. M., \& Nahata, R. (2012). Internal corporate governance, CEO turnover, and earnings management. Journal of Financial Economics, 104(1), 44-69.

Hessayri, M., \& Saihi, M. (2015). Monitoring Earnings Management in Emerging Markets IFRS Adoption and Ownership Structure. Journal of Economic and Administrative Sciences, 31(2), 86-108.

Hoang, K. M. T., \& Phung, T. A. (2019). The effect of financial leverage on real and accrual-based earnings management in vietnamese firms. Economics and Sociology, 12(4), 285-298.

Hu, N., Hao, Q., Liu, L., \& Yao, L. J. (2015). Managerial tenure and earnings management. International Journal of Accounting and Information Management, 23(1), 42-59.

Ifada, L. M., \& Wulandari, N. (2015). The Effect of Deferred Tax and Tax Planning Toward Earnings Management Practice. International Association of Organizational Innovation, 8(4), 155170.

Ilmas, F., Tahir, S., \& Asrar-ul-Haq, M. (2018). Ownership Structure and Debt Structure As Determinants of Discretionary Accruals: An Empirical Study of Pakistan. Cogent Economics and Finance, 6(1).

Jiang, F., Ma, Y., \& Wang, X. (2020). Multiple blockholders and earnings management. Journal of Corporate Finance, 64, 101689.

Jones, J. J. (1991). Earnings Management During Import Relief Investigations. Journal of Accounting Research, 29(2), 193.

Kablan, M. A. (2020). The Effect of Ownership Structure on Earnings Management Practices Toward Achieving the Real Comprehensive Income "An Applied Study on the Listed Companies 
in Libyan Stock Market". 2020.

Kumala, R., \& Siregar, S. V. (2020). Corporate social responsibility, family ownership and earnings management: the case of Indonesia. Social Responsibility Journal, 17(1), 69-86.

Lakhal, N. (2015). Corporate disclosure, ownership structure and earnings management: The case of french-listed firms. Journal of Applied Business Research, 31(4), 1493-1504.

Lassoued, N., Ben Rejeb Attia, M., \& Sassi, H. (2017). Earnings management and ownership structure in emerging market: Evidence from banking industry. Managerial Finance, 43(10), 1117-1136.

Lazzem, S., \& Jilani, F. (2017). The impact of leverage on accrualbased earnings management: The case of listed French firms. Research in International Business and Finance, 44, 350-358. http://dx.doi.org/10.1016/j.ribaf.2017.07.103

Lemma, T. T., Negash, M., Mlilo, M., \& Lulseged, A. (2018). Institutional ownership, product market competition, and earnings management: Some evidence from international data. Journal of Business Research, 90(December 2017), 151-163.

Maheshwari, Y., \& Agrawal, K. (2015). Impact of IPO Grading on Earnings Management. Journal of Financial Reporting and Accounting, 13(2), 142-158.

Mahjoub, I., \& Miloudi, A. (2015). Earnings Management: a Review of Literature. Euro and the European Banking System: Evolutions and Challenges, December, 691-703.

Mery, K. N. (2017). Pengaruh Likuiditas, Leverage Dan Profitabilitas Terhadap Nilai Perusahaan Dengan Kebijakan Dividen Sebagai Variabel Moderasi Pada Perusahaan Pertambangan Yang Terdaftar Di Bursa Efek Indonesia Tahun 2011-2014. JOM Fekom, 4(1), 2000-2014.

Moslemany, R. El, \& Nathan, D. (2019). Ownership structure and earnings management: Evidence from EgyPT International Journal of Accounting and Information Management, 7(1), 135-161.

Nasution, L. M. (2017). Statistik deskriprif. Jurnal Hikmah, 14.

Noe, K., Forgione, D. A., Smith, P. C., \& Liu, H. (2017). Earnings Management In Non-Public Companies: The Case of For-Profit Hospice Organizations. J. Of Public Budgeting, Accounting \& Financial Management, 29(1), 1-19.

Nurdiniah, D., \& Herlina, L. (2015). Analysis of Factors Affecting the Motivation of Earnings Management in Manufacturing Listed in Indonesia Stock Exchange. Research Journal of Finance and Accounting, 6(3), 100-107.

Okoro, E. G., \& Ihenyen, C. J. (2020). Does earnings management exert pressure on firms' return on assets and equity? The case of sub-saharan africa. Economic Horizons, 22(3), 221-233.

Oz, I. O., \& Yelkenci, T. (2018). Examination of real and accrual earnings management: A cross-country analysis of legal origin under IFRS. International Review of Financial Analysis, 58(July 2017), 24-37.

Paiva, I. S., Lourenço, I. C., \& Branco, M. C. (2016). Earnings Management in Family Firms: Current State of Knowledge and Opportunities For Future Research. Review of Accounting and Finance, 15(1), 85-100.

Patel, J. D. (2020). Determinates of Earnings Management: A Study of Selected Indian FMCG ( Fast Moving Consumer Goods ) Companies. International Journal of Research and Analytical
Review, 7(2), 785-794.

Perdana, A. A. (2019). The Influence of Institutional Ownership, Leverage, and Audit Committee on Earnings Management: Evidence of Companies Listed on the Indonesia Stock Exchange. Journal of Accounting Research, Organization and Economics, 2(2), 97-112.

Pirzada, K., Susanto, Y. K., \& Adrianne, S. (2019). Is tax aggressiveness an indicator of earnings management? Polish Journal of Management Studies, 20(2), 516-527.

Pramithasari, A. A. P. K., \& Yasa, G. W. (2017). The effect of good corporate governance on earnings management in companies that perform IPO. The Indonesian Accounting Review, 6(1), 37.

Purnama, I., \& Nurdiniah, D. (2019). Profitability, Firm Size, and Earnings Management: the Moderating Effect of Managerial Ownership. Advances in Economics, Business and Management Research, 73, 41-46.

Putri, F. A., \& Machdar, N. M. (2018). Pengaruh Asimetri Informasi Dan Ukuran Perusahaan Terhadap Manajemen Laba. Balance Vocation Accounting Journal, 1(2), 1.

Qi, B., Yang, R., \& Tian, G. (2013). Can media deter management from manipulating earnings? Evidence from China. Review of Quantitative Finance and Accounting, 42(3), 571-597.

Rahnamay Roodposhti, F., \& Nabavi Chashmi, S. A. (2010). The effect of board composition and ownership concentration on earnings management: Evidence from Iran. World Academy of Science, Engineering and Technology, 66(6), 165-171.

Ranjbar, S., \& Amanollahi, G. F. (2018). The effect of Financial Distress on Earnings Management and Unpredicted Net Earnings in Companies Listed on Tehran Stock Exchange. Management Science Letters, 8(9), 933-938.

Razzaque, R. M. R., Ali, M. J., \& Mather, P. R. (2016). Real earnings management in family firms: Evidence from an emerging economy. Pacific Basin Finance Journal, 40, 237-250.

San Martin Reyna, J. M. (2018). The effect of ownership composition on earnings management: evidence for the Mexican stock exchange. Journal of Economics, Finance and Administrative Science, 23(46), 289-305.

Santo Paolo, S. A. of family control in the practice of earnings $m$, Andreia, C. D., \& Debora, G. M. (2013). Influence of Family Control in the practice of earnings management: The case of open brazilian companies. Management Research, 11(1), 77-99.

Saona, P., Muro, L., \& Alvarado, M. (2020). How do the ownership structure and board of directors' features impact earnings management? The Spanish case. Journal of International Financial Management and Accounting, 31(1), 98-133.

Setianto, R. H., \& Sari, P. K. (2017). Perusahaan Keluarga dan Kebijakan Dividen di Indonesia. Jurnal Siasat Bisnis, 21(2), 107118.

Soliman, M. M., \& Ragab, A. A. (2013). Board of Director's Attributes and Earning Management: Evidence from EgyPT Proceedings of 6th International Business and Social Sciences Research Conference, 1-20.

Susanto, Y. K. (2016). the Effect of Audit Committees and Corporate Governance on Earnings Management: Evidence From Indonesia Manufacturing Industry. International Journal of 
Business, Economics and Law, 10(1), 32-37.

Wan Mohammad, W. M., \& Wasiuzzaman, S. (2019). Effect of audit committee independence, board ethnicity and family ownership on earnings management in Malaysia. Journal of Accounting in Emerging Economies, 10(1), 74-99.

Wirianata, H. (2020). Analysis of Factors Affecting Earnings Management Moderated by Institutional Ownership. Jurnal Akuntansi, 24(1), 1.
Wu, R. S. (2014). Predicting earnings management: A nonlinear approach. International Review of Economics and Finance, 30, $1-$ 25 .

Zulvina, Y. (2015). Pengaruh Komisaris Independen, Komite Audit dan Blockholders Terhadap Earnings Management. Jom FEKON, 2(2), 1-15. 